\title{
"We have a law ...": The Trials of Jesus of Nazareth
}

\author{
R. P. Booth ${ }^{\star}$
}

To the Roman judge, Pilate - so records the Evangelist, John - the Jews protested that they had a law, and by that law Jesus should die because he had made himself the Son of God. ${ }^{1}$ This claim illustrates the conflict of laws permeating the proceedings which culminated in Jesus' crucifixion. Even amongst the Jews, the Pharisees and the Saducees followed different versions of theocratic law, but had, perforce, to unite to frame charges that would induce a Roman court to pronounce a death penalty. In addition to the interplay of different legal systems, the uncertain boundary between judicial decision and executive action is explicit in the proceedings before Pilate, and implicit in the attendance before Herod. Another aspect of this conflict lies in the contrast between Jewish culture in which law is the will of God and thus theology, and Roman culture where law is the will of a human sovereign. Thus, the historical importance of the trials of Jesus can hardly be over-estimated; their impact on subsequent relations between Jews and Gentiles was cataclysmic, and their religious significance for the Christian is self-evident. They also constitute a fascinating study for the comparative lawyer. Pursuing what has been termed the 'forensic' method, ${ }^{2}$ an attempt will be made in this essay to assess the often conflicting literary evidence about the trials, and to determine how far the evidence thus found to be more probably authentic, is supported by the relevant law of that period.

* Solicitor. Formerly Senior Lecturer in Law, University of Buckingham.

1. 19,7. The translation of the New Testament used in this essay is the Revised Standard Version.

2. This involves treating the Gospel statements mutatis mutandis as if they were the depositions of a witness in civil litigation. They are thus liable to be over-ridden by stronger evidence to the contrary, but if unopposed will be accepted unless their content is intrinsically improbable. Admittedly, the weight to be attributed to Gospel assertions as evidence is reduced by the greater credulity of the ancients and by the possible distortion of the tradition in its oral transmission and translation into Greek. This approach is, however, to be contrasted with that of many radical New Testament critics who consider there is so much dubious material in the Gospels that their study of a statement commences with a presumption of its inauthenticity. We explain our method more fully in fesus and the Laws of Purity, Sheffield Academic Press (1986), pp. 15-18 and in Contrasts - Gospel Evidence and Christian Beliefs, Paget Press (1990), pp. 1-11. 
The bulk of the evidence of the proceedings is found in the Christian Gospels. Underlying the Gospel accounts there seem to be three sources or eye-witnesses ${ }^{3}$ who are largely independent of each other. Mark provides the earliest 'law report' of Jesus' trials (including arrest). ${ }^{4}$ Matthew ${ }^{5}$ substantially follows (i.e., copies) Mark, and although he includes some new material (e.g., the dream of Pilate's wife and Pilate's washing of his hands $),{ }^{6} \mathrm{it}$ is marginal to the course of the proceedings. Luke's version ${ }^{7}$ supports much of Mark's evidence, but introduces from his own source (' $L$ ' not the common source, ' $Q$ ') ${ }^{8}$ important additional material (e.g., the allegations before Pilate of perverting the nation and forbidding tribute) which is discussed below. Because of this new material and because Luke's Greek vocabulary differs materially from Mark's in the places where his narrative does agree with Mark's, it seems that Luke's report stems not only from a different tradent $^{9}$ but from a different eye-witness or witnesses. Again, John's report of the trials ${ }^{10}$ is so different in content from Mark's and Luke's that he may well represent a third independent eye-witness whose assertions must be weighed.

Other early Christian evidence is of a general nature. ${ }^{11}$ The only Talmudic ${ }^{12}$ evidence of the judicial reason for Jesus' death is at Sanhedrin 43a; "On the eve of Passover Yeshu was hanged. For forty days before the execution took place, a herald went forth and cried, '[Yeshu] is going forth to be stoned because he has practised sorcery and enticed Israel to apostasy. Anyone who can say anything in his favour, let him come forward and plead on his behalf.' But since nothing was

3. In the main, the Evangelists collected stories which had first been related by eye-witnesses and then passed on, usually orally, until they reached an Evangelist. If the author of John's Gospel was "the beloved disciple" $(13,23)$, then he was an eye-witness himself. Mark, too, may have been a first-hand witness of some events $(14,51)$, particularly if he was the son of the Mary whose home was a rendezvous of the first Christians; additionally, he is said to have been the 'interpreter' of Peter.

4. Probably, Mark wrote his Gospel in A.D. 65-7, and Matthew and Luke between 80 and 100 A.D.. Of Mark's 661 verses, Matthew repeats in very similar Greek 600 and Luke, 350 . Therefore, most scholars agree that Matthew and Luke copied from Mark. See further hereon, B. H. Streeter, The Four Gospels, Macmillan (1927), Ch. VII.

5. 26,47-27,31.

6. 27,$19 ; 27,24$.

7. $22,47-23,25$.

8. In addition to Mark's Gospel, Matthew and Luke used another source, probably written, called ' $Q$ ' (German, Quelle, source) from which they copied. But each used also his private source of tradition called by scholars ' $M$ ' and ' $L$ ' respectively.

9. A tradent is a person who passed on orally the stories about Jesus before they reached the Evangelist. The different routes which the stories could take before reaching the Evangelists, and the complexities involved in examining whether a similar story contained in two or more Gospels originated with separate eye-witnesses, or were merely passed down wholly or partly different lines of tradents, are discussed by the present writer in Contrasts, supra n. 2, pp. 112-16.

10. $18,2-19,16$.

11.E.g., 1 Thessalonians 2,15: ". . the Jews who killed both the Lord Jesus and the prophets". There is specific evidence in the Acts of the Apostles $(3,13-15 ; 13,27-28)$, but since that book was also written by Luke, we class it with his Gospel.

12. The references in this essay are to the Babylonian Talmud, although there is also a Palestinian Talmud. The former contains the Mishnah (see n. 47 infra) with commentary and discussion on it by later Rabbis, and was finally compiled, c. 550 A.D.. 
brought forward in his favour, he was hanged on the eve of the Passover."13 Although this is useful support for John's assertion that Jesus was crucified on the day before Passover, ${ }^{14}$ the assertions of charges of sorcery and leading Israel astray and of a leisurely wait for a defence, are outweighed by the cumulative Gospel evidence to be adduced below. There is scant evidence about the trial in secular histories of the time. Josephus, the Roman-Jewish historian, wrote c. 93 A.D.: "When Pilate, upon hearing [Jesus] accused by men of the highest standing among us, had condemned him to be crucified, those who had in the first place come to love him, did not give up their affection for him." 15 Part of the passage about Jesus in which the quoted words appear (the Testimonium Flavianum) is considered to have been interpolated by Christians, but this neutral sentence may well be genuine. It alleges the participation of both the Jews and Pilate in the proceedings, but does not state the charges. Tacitus, writing c. 115-7 A.D., only mentions Pilate. Speaking of the Christians, he said: "Christus, the founder of the name, had undergone the death penalty in the reign of Tiberius by sentence of the procurator, Pontius Pilate."16

It is, therefore, the Gospel evidence which we must assess in an attempt to establish the likeliest course of the proceedings which led to the crucifixion. For ease of examination these proceedings can be separated into the Arrest, the Proceedings before the Jews, the Proceedings before Pilate, the Proceedings before Herod, and the Judgment of Pilate.

\section{The arrest}

Mark speaks of an arresting party comprising Judas with "a crowd with swords and clubs, from the chief priests and the scribes and the elders." 17 Luke, also, describes a Jewish arresting party, for he refers to the "chief priests and captains of the temple and elders, who had come out against [Jesus]." 18 However, John asserts that Judas arrived with a "band of soldiers and some officers from the chief priests and the Pharisees," 19 and later calls them, "the band of soldiers and their captain and the officers of the Jews." 20 The Greek words translated "band of soldiers" and "captain" are respectively speira and chiliarchos; the former strictly means a Roman cohort and the latter, the commander of a thousand Roman soldiers. Thus, we already have a conflict of evidence with Mark and Luke attesting a Jewish arrest and John, a combined Roman and Jewish one. It is doubtful, though, that Mark and Luke can be treated as separate witnesses on this issue. Although their

13. E. T. Soncino, Nezikin, Vol. III, p. 281.

14. John 13,$1 ; 18,28$. Mark $(14,12)$ and Luke $(22,14)$ place the crucifixion on the Passover.

15. Antiquities 18,64 (E. T. Loeb, Vol. IX, p. 51).

16. Annals 15,44 (E. T. Loeb, Vol. V, p. 283).

17. 14,43 .

18. 22,52 .

19. 18,3 .

20. 18,12 . 
comparable passages ${ }^{21}$ describing the arrest are similar, there are sufficient differences to suggest that Luke is not copying Mark; the similarities, however, make it likely that their reports of the arrest emanate from a common witness. Thus, we have one witness (John's source) asserting Roman involvement in the arrest, and one witness (Mark's and Luke's source) denying it. Mark is writing sooner after the event than John, but the Passion story, including the trial is thought to have acquired a fairly fixed form at an early date, so John's source may likewise be early. The possible historicity of much of John's narrative has been increasingly recognised by modern scholars. As C. H. Dodd has written: "behind the Fourth Gospel lies an ancient tradition independent of the other Gospels, and meriting serious consideration as a contribution to our knowledge of the historical facts concerning Jesus Christ." 22

Since the literary evidence is evenly balanced between Mark/Luke and John, we must investigate other evidence of the identity of the arresters. Opposing John's evidence that a cohort of soldiers attended Judas, is the very size of a cohort which comprised a tenth of a legion which in turn comprised 3-6,000 men. So a cohort comprised at least 300 men and probably more, ${ }^{23}$ since it was commanded by a chiliarch, literally the commander of 1000 men. Admittedly, a cohort of soldiers was permanently stationed in the Antonia citadel on the North side of the Temple, ${ }^{24}$ but it seems unlikely that so large a contingent would be commissioned to arrest one man even if his attendants might be armed, for Judas would presumably have told the chief priests of the small number of Jesus' group of disciples. When, about 25 years later, Paul was arrested by the tribune of the cohort after being mobbed by the crowd in the temple, Luke only records that the tribune "took soldiers and centurions," 25 i.e., presumably not the whole cohort. On the other hand, this counter-evidence argues mainly against John's assertion of the size of the Roman contingent, and only to a lesser extent casts doubt on John's accuracy as to the presence of any Roman soldiers. The fact, attested by all the Evangelists, that Jesus was taken to the high priest's house, indicates that the arrest was probably instigated by the Jews, ${ }^{26}$ so we must search for evidence as to whether or not the Jews could obtain assistance from the Romans in arresting a person for the purpose of Jewish legal proceedings. To this end, there follows a brief survey of the relationship between Roman and Jewish jurisdiction in Judaea at this time.

In 63 B.C., the Roman Pompey had defeated in battle the last of the native Maccabean rulers, and had conquered Palestine. In conformity with their usual colonial practice, the Romans reserved the maintenance of law and order to

21. Mark 14,43-52 and Luke 22,47-53.

22. Historical Tradition in the Fourth Gospel, Cambridge (1963), p. 423.

23. See E. Schürer, The History of the Jewish People in the Age of Jesus Christ, T. \& T. Clark (1973), Vol. I, pp. 362-3.

24. Op. cit., p. 366.

25. Acts 21,32 .

26. Contra, P. Winter, On the Trial of Jesus, De Gruyter, Berlin (1961), pp. 48-9. 
themselves, but successive rulers allowed the Jews continued self-government in matters of private law. ${ }^{27}$ The reserved law was administered on behalf of Rome by puppet kings or tetrarchs like the Idumean Herods or, more directly, by a Roman praefectus at Caesarea. On Herod the Great's death in 4 B.C. the rule of Judaea was granted by Augustus to Herod's son, Archelaus, and that of Galilee to Herod's son, Antipas. Due to Archelaus' mis-rule he was deposed in A.D. 6 and Judaea became a Roman province governed by a praefectus. Pontius Pilate was praefectus from A.D. 26 to 36 and was hated by the Jews because of his disregard for their customs and privileges. He had ordered his troops to enter Jerusalem with ensigns bearing the emperor's image (which contravened the second Mosaic commandment), and had applied the treasures of the temple to the building of an aqueduct. ${ }^{28}$ In view of this mutual hostility it seems unlikely that the chief priests would seek the assistance of the Romans to effect an arrest which their temple officers could easily achieve; nor is it likely that the Romans would give such assistance if requested.

In exercise of their imperium through the power of coercitio the Romans could arrest in Judaea whomsoever they wished, but they would normally use this power only where law and order, and hence Rome's dominium, were threatened. Thus, even when the tribune ordered Paul's arrest, it was because "all Jerusalem was in confusion" during the attempt at lynch-justice, not because of Paul's alleged preaching against Jewish law, and defilement of the temple. ${ }^{29}$ His subsequent defence before Felix, the governor, was that he had not caused a disturbance in the temple, the synagogues or the city. ${ }^{30}$ Moreover, the Jewish authorities did not themselves lack power to apprehend; on two occasions they arrested apostles in Jerusalem, ${ }^{31}$ and Paul apparently obtained authority from the high priest to arrest Christians even outside Palestine, in Damascus. ${ }^{32}$ Since there was no public commotion at the time of Jesus' arrest, we find Mark's evidence (supported by Luke's version) more probable, namely that Jesus' arrest was effected by Judas and others sent from the chief priests, scribes and elders being the three component parts of the Sanhedrin. This was the supreme judicial and legislative body for civil and unreserved criminal law in Judaea, subject always to the Romans' power to intervene. It is very likely that prominent among the arresting party were the captains of the temple and their assistants, i.e., the temple police who would enforce the wishes of the chief priests or the Sanhedrin. On receiving

27. Thus Josephus reports that when Julius Caesar in 47 B.C. appointed Hyrcanus and his children to be ethnarch and high priest of the Jews, they were given such high priestly rights as existed in accordance with their laws, and "if any question shall arise concerning the Jews' manner of life, it is my pleasure that the decision rests with [Hyrcanus and his children]': Antiquities 14, 194-5.

28. Josephus, Antiquities 18,55-62; War 2, 169-177. According to the Mishnah the building of an aqueduct was arguably an authorised use of temple funds (Shekalim 4, 2).

29. Acts $21,28-32$.

30. Acts $24,11-12$.

31. Acts 4,$3 ; 5,17$.

32. Acts $9,1-2 ; 26,12$. 
Judas' information, ${ }^{33}$ the chief priests may themselves have had authority to bring Jesus before the Sanhedrin in its aforesaid capacity as a criminal court. The next scene is before the high priest, who was the president of the Sanhedrin. ${ }^{34}$

\section{Proceedings before the Jews}

According to Mark, ${ }^{35}$ Jesus' arresters lead him to the high priest, presumably to his house as Matthew interprets, ${ }^{36}$ where all the chief priests, elders and scribes were gathered. Luke ${ }^{37}$ states that Jesus was led to the high priest's house, but he mentions no meeting until the morning. According to John, ${ }^{38} \mathrm{Jesus}$ was led to the house of Annas, a former high priest (but, following custom, still called 'high priest'). The evidence concerning the nature of this nocturnal proceeding conflicts. Mark appears to assert that it was a formal meeting of the Sanhedrin for "the chief priests and the whole council sought testimony against Jesus to put him to death"; 39 the Greek word here translated "council", is sunedrion, i.e., Sanhedrin. In Luke, there is no meeting of the Jews at night - Jesus is just detained until a morning meeting. ${ }^{40}$ In John, Jesus is questioned by Annas only and then sent to Caiaphas (the high priest in office), but he is not brought before the Sanhedrin until early the following morning. ${ }^{41}$ Thus, the only witness attesting a night meeting of the Sanhedrin is Mark's source, whereas the accounts of Luke and John, which deny a night meeting, are otherwise so different in content as to postulate separate witnesses lying behind them. The weight of the literary evidence is therefore opposed to a nocturnal meeting of the Sanhedrin.

Against this literary evidence we must place the external evidence that (a) if the Sanhedrin were to meet at night, the house of the high priest would be a natural place, since the "Hall beside the Xystus"42 (the normal meeting place) would be inaccessible after the gates to the Temple Mount had been closed at night, and (b) as A. N. Sherwin-White has shown, ${ }^{43}$ if there had been only one meeting of the Sanhedrin, and that in the morning, it would have required great haste to resolve the Jewish legal issues and bring charges to Pilate before the start of his latemorning leisure; Roman gentlemen normally arose early, and had finished their matutinal labours by about the start of the sixth hour (after sunrise).$^{44}$ Since Jesus

33. Mark 14,10-11.

34. Schürer, supra n. 23, Vol. II, p. 215.

35. 14,53 .

36. 26,57 .

37. 22,54 .

38. 18,13 .

39. 14,55 .

40. 22,66 .

41. 18,28 .

42. Incorrectly called in the Mishnah, "The Chamber of Hewn Stone": see Schürer, supra n. 23, Vol.

II, pp. $223-5$.

43. In Roman Society and Roman Law in the New Testament, Oxford (1963), pp. 44-6.

44. See also J. Carcopino, Daily Life in Ancient Rome, Routledge (1941), pp. 150-2. 
was crucified at or shortly before that hour, ${ }^{45}$ it would have been necessary for the Jews to have approached Pilate not much later than the fourth hour, i.e., about 10.00 a.m.. ${ }^{46}$ Sherwin-White is surely right to say that to reach Pilate in time would have been difficult without a nocturnal meeting of the Sanhedrin unless the proceedings of the Sanhedrin were much shorter than Mark indicates. On the other hand, evidence supporting Luke and John's denial of a night meeting is the Mishnah's provision at Sanhedrin 4,1 that capital cases (i.e., those involving the death penalty) were not to be tried at night. This evidence is weakened, though, by uncertainty as to whether this provision, which was finally compiled c. A.D. $200,{ }^{47}$ prevailed in the time of Jesus. Some of the detailed Court procedure there set out suggests the refining of later years; the fluidity of the Jewish legal system prior to the destruction of the temple in A.D. 70 is discussed below. Assessing the literary and external evidence together, Mark's evidence supported by the evidence of the time factor does produce a balance of probability in favour of a nocturnal meeting.

But what kind of a trial took place at this nocturnal meeting? According to Mark, it was a formal meeting of the Sanhedrin, and this seems more probable than John's evidence that Jesus was questioned by Annas alone and then sent on to Caiaphas, for apart from Peter's denial we are not told what, if anything, happened there; the sequence as recorded seems to indicate little judicial purpose. In Luke, as already mentioned, nothing happened at night. However, Luke and Mark agree that there was a formal meeting of the Sanhedrin at some time so that John's evidence of an informal questioning by Annas is outweighed. Klausner has argued that the meeting of the Sanhedrin was not convened to try Jesus for offences against Jewish law, but was rather a preliminary investigation whose result would have been submitted to Pontius Pilate for full adjudication under Roman law if he thought appropriate. ${ }^{48} \mathrm{Klausner}$ cites the numerous Egyptian papyri containing records of trials conducted by the Romans and showing that the Roman governors of Egypt entrusted preliminary enquiries to the local Egyptian authorities. There is no record in Josephus or elsewhere that this procedure was applied in Judaea, and the hostile relations described above render it unlikely that the Sanhedrin would assist the Roman judicial system in this way. Josephus does report the case of Jesus, son of Ananias, who in the seventh decade A.D. continually prophesied destruction upon Jerusalem and the temple, and did not desist even after chastisement by order of the Sanhedrin. He was then delivered by that Court to Albinus the Roman procurator for more severe scourging (which did not terminate

45. Mark 15,33; Luke 23,44.

46. Time was never more than approximate, when timekeeping depended on the sun-dial and the water-clock, and sun-rise was a changing base: see Carcopino, supra n. 44, pp. 148-150.

47. The Mishnah contains the rulings of the scribes and Rabbis on many aspects of Jewish life which were passed on orally until committed to writing in the 2 nd century A.D. and finally compiled in this book. It includes rulings dating from $c .200$ B.C., but the difficulty of dating early Rabbinic material is great and, with some proposals, is discussed by the present writer in fesus, supra n. 2, pp. 130-50. Citations from the Mishnah state the tractate (chapter) title sometimes preceded by ' $M$ '.

48. Jesus of Nazareth, E. T. Macmillan (1925), pp. 333-4. 
the dirge - Albinus pronounced him mad and let him go!)..$^{49}$ There, however, the Sanhedrin did not conduct a mere preliminary investigation. It transferred the case not for full trial but for greater penalty.

Regarding the charges levelled at Jesus in the nocturnal Sanhedrin trial, both Mark and Luke assert that the high priest asked Jesus whether he was the Christ, the Son of the Blessed (Luke - Son of God); ${ }^{50}$ in Luke the two titles were put to Jesus separately, and are the only accusations laid before the Sanhedrin. Now, as the Court's function was presumably to investigate offences against Jewish law, the high priest's questions were irrelevant since 'Christ' (christos) was the Greek translation of the Hebrew massiah (literally, the anointed one), and it was no offence against Jewish law mistakenly (or correctly!) to claim to be the Messiah; indeed, there were several aspirant Messiahs around the time of Jesus (see below), and no action was taken against them by the Jews. For after all, the Messiah was to be a national military hero in the model of King David, who would rid the Jews of the Roman yoke. A typical view of the Messiah's role is expressed in a Psalm of Solomon thought to be the work of a Pharisee in the period 63-48 B.C.:

"Behold, O Lord, and raise up unto them their king, the son of David, in the time which thou, O God, knowest, that he may reign over Israel thy servant; And gird him with strength that he may break in pieces them that rule unjustly.

Purge Jerusalem from the heathen that trample her down to destroy her, with wisdom and with righteousness." 51

A claim to be such a figure was, amongst the Jews, laudable rather than indictable. A claim to be the Son of God was similarly considered to be unobjectionable, even if extravagant. This title was first used of Israel itself, ${ }^{52}$ and the king came to hold it as the representative of the people. ${ }^{53}$ The discovery of the Dead Sea Scrolls has provided evidence that in the years before Jesus' birth the Davidic Messiah figure was gaining esteem as the Son of God (4Q Florilegium, 10-14).

Thus, claims to be the Christ or the Son of God did not approach the legal definition of blasphemy. It is ruled at Leviticus 24,15 that "Whoever curses his God shall bear his sin," and in v. 16 that "He who blasphemes the name of the Lord shall be put to death." The Hebrew word-root translated 'curses' in v.15 (q-1-1), can bear the wider meaning of 'dishonour', but the root translated 'blasphemes' in v.16 ( $\mathrm{n}-\mathrm{q}-\mathrm{b}$ ), literally means 'pierce' (the Name) and it is,

50. Mark 14,61; Luke 22,67,70.

51. Psalm 17,23-25, E. T. H. E. Ryle and M. R. James, Psalms of the Pharisees, Cambridge (1891), pp. 137-8.

52. Exodus 4,22-23; Hosea 11,10.

53. 2 Samuel 7,14; Psalm 2,7. 
perhaps, in reliance on this strict meaning that the scribes, according to the Mishnah, ${ }^{54}$ ruled that the accused is not culpable unless he pronounces the divine Name (the Tetragrammaton, $y-h-w-h$ ) itself. It is possible that in Jesus' day more weight was given to the v.15 aspect of 'dishonouring' God, but as discussed above, claims to be the Messiah or the Son of God could not be so construed.

Moreover, we cannot be sure that the Sanhedrin followed the Mishnaic law on the definition of blasphemy in Jesus' trial and on other legal issues even if the law in the Mishnah was current in Jesus' day. For the rulings in the Mishnah are by Pharisaic scribes and Rabbis, since the legal approach of the Pharisees dominated in Judaism after the fall of the temple in A.D. 70 and the consequent eclipse of the priestly Sadducaic party. In Jesus' time, the chief priests and the other Sadducaic aristocracy were the major party in the Sanhedrin, although there was a substantial Pharisaic minority. ${ }^{55}$ In contrast to the Pharisees, who gave force to the written law of the scriptures as interpreted and extended by the oral decisions of the scribes (later written down in the Mishnah), the Sadducees considered only the written law as binding, and this created hostility between the two parties. ${ }^{56} \mathrm{~A}$ judicial consequence of the different approaches is shown in the definition of blasphemy. The Sadducees would probably give force to v. 15 of Leviticus 24 which, as already discussed, includes the dishonour of $\mathrm{God}^{57}$ whereas the Pharisees, giving greater weight to v.16's reference to the Name of the Lord, would only find blasphemy where the Tetragrammaton was uttered (and only then if a prior warning had been given!). Notwithstanding the Sadducaic majority in the Sanhedrin, in many matters the legal views of the Pharisees prevailed over those of the Sadducees because otherwise the mass of the people who revered the Pharisees would not tolerate the Sadducees in official positions. ${ }^{58}$ It seems, however, from Mark 2,7 that the wider definition of blasphemy based only on the written law was accepted even by the scribes in Jesus' day, for there some scribes, having heard Jesus purport to forgive sins, protest that it is blasphemy since "Who can forgive sins but God alone?"

Regarding the charges of blasphemy before the high priest, even if Jesus had claimed to be the Son of Man, that would hardly have constituted dishonour of God. Although that Son was the first of creation, ${ }^{59}$ and a heavenly being, ${ }^{60}$ and came to God with the clouds of heaven, ${ }^{61}$ he was conceived of as a separate person, quite distinct from God.

\section{Sanhedrin 7,5.}

55. See Acts 23,6-10.

56. As evinced at Acts 23,6-10 and M. Yadaim, 6-8; Josephus, Antiguities, 13, 297-8.

57. But see, contra, H. Cohn, The Trial and Death of fesus, Harper \& Row (1967), pp. $101-3$.

58. Josephus, Antiquities, 18,17.

59. Enoch 48,1 .

60. Enoch 46,2.

61. Daniel 7,13. The view of R. Akiba (fl. c. 120-40) that David and God sat side by side on the thrones mentioned at Daniel 7,9, although criticised, did not provoke allegations of blasphemy (Sanhedrin $38 b$ ). 
In addition to the substantive law, there is evidence from the Jewish law of procedure militating against a conviction of Jesus for blasphemy in that a confession by the accused is unlikely to have formed sufficient evidence to justify such a conviction. Both the Deuteronomic Code (early 7th Century B.C.) ${ }^{62}$ and the Tosephta (c.200 A.D. $)^{63}$ stipulated that the evidence of two witnesses was necessary to convict on a capital charge, so that this was almost certainly the law in the time of Jesus. The possibility that the accused's admission would remove the need for other witnesses is excluded, according to the scribes, by another Tosephta provision ${ }^{64}$ that one of the differences between civil and criminal cases is that whereas in civil cases a person is bound by his own admission, in criminal cases a confession, in or out of Court, is not evidence against him. ${ }^{65}$

Nonetheless, Mark asserts that after Jesus had admitted being the Christ, the Son of the Blessed (God), and added that the high priest would see the Son of Man sitting at the right hand of Power and coming with the clouds of heaven, the high priest declared this to be blasphemy, tore his coat (as was legally required) ${ }^{66}$ and the Sanhedrin condemned Jesus as deserving death. ${ }^{67}$ It thus seems clear that it is the claim to be the Christ, the Son of God, which the priest treats as blasphemous since Jesus has not claimed to be Son of Man - he has told the priest only that he, the priest, will see that Son. In contrast to Mark, in Luke, on hearing Jesus' admission that he was the Son of God, the Sanhedrin did not pronounce him guilty of blasphemy, but asked rhetorically what further testimony they needed. ${ }^{68}$ This indicates not that they had convicted him of a Jewish offence but rather that they had obtained the evidence necessary to convict him of a Roman offence before Pilate. The psalm of Solomon (supra) shows what a direct threat to Rome's dominium a claim to be the Davidic Messiah constituted.

Supporting Mark's assertion of blasphemy is John's assertion of a general allegation by the Jews that "We have a law, and by that law he ought to die, because he has made himself the Son of God." 69 Pitted against these assertions is the evidence of substantive and procedural law that the admissions could not support a conviction for blasphemy, and on a balance of probability Luke's evidence is preferable - that the admissions provided rather the testimony which the Sanhedrin expected Pilate to accept as showing treason.

Yet other charges were levelled at Jesus before the Sanhedrin according to

62. Deuteronomy 17,6 (capital offence) and 19,15 (any offence); Numbers 35,30 (capital offence).

63. Sanhedrin 11,1 . The Tosephta ("the added things") is a collection of rulings traditionally thought to be supplemental to those in the Mishnah, and to have been compiled shortly after the Mishnah. It is sometimes cited by a ' $T$ ' before the tractate title.

64. Shevuot 3,8 .

65. If the confession is itself blasphemous, it is arguable that those present in Court could in a second trial give evidence of that blasphemy.

66. M. Sanhedrin 7,5 .

67. 14,62-64.

68. $22,70-71$.

69. 19.7. 
Mark. ${ }^{70} \mathrm{He}$ records that many bore false witness against Jesus, but their witness did not agree. The only specific allegation Mark reports is that some falsely witnessed that they had heard Jesus say, "I will destroy this temple that is made with hands, and in three days I will build another, not made with hands." 71 Mark adds that even these witnesses did not agree, but Matthew implies his understanding that they did, for he reports, "At last two came forward and said, "This fellow said, "I am able to destroy the temple of God, and to build it in three days.".,"72 This hearsay seems to be a distortion of a claim of Jesus which John reports, "Destroy this temple and in three days I will raise it up", ${ }^{73}$ where John adds that Jesus spoke of the temple of his body. In any case, in John, Jesus is not threatening to destroy the temple, he is claiming what he could do if it were destroyed. Evidence supporting the authenticity (and the truth) of the temple allegation at Jesus' trial is provided by Luke's source; witnesses (false, says Luke) at the trial of Stephen, about three years later, testified, "we have heard [Stephen] say that this Jesus of Nazareth will destroy this place, and will change the customs which Moses delivered to us." 74

It seems more probable that Jesus merely prophesied the destruction of the temple (correctly) rather than personally threatened to destroy it. For in Mark, Jesus says outside the temple, "Do you see these great buildings? There will not be left one stone upon another that will not be thrown down."75 Jesus uttered similar prophecies of doom on God's Day of Judgment for Jerusalem ${ }^{76}$ and Chorazin, Bethsaida and Capernaum. ${ }^{77}$ But, of course, the Sanhedrin was solely and rightly concerned with the evidence given before it, namely (according to Mark) that Jesus had threatened to destroy the temple. It is not inconsistent that Mark reports two witnesses as having testified in the quoted identical words, and yet states that their evidence did not agree. ${ }^{78}$ As already noted, the Deuteronomic Code provided that a man should not be convicted of any capital offence on the evidence of a single witness. This was interpreted to mean that the evidence of the two or more witnesses must agree exactly. Thus, in the History of Susannah (written c.B.C. 150-200) the conviction of Susannah for adultery was set aside when, on reexamination, one witness said that the act took place under a mastick tree, while the other said under a holm tree. ${ }^{79}$ The law seems gradually to have increased in strictness, since in later times according to the Mishnah, the witness was asked on what date in the month, on what day, at what hour and in what place it was

70. $14,56-59$.

$71.14,58$.

72. $26,60-61$.

73. 2,19 .

74 . Acts 6,14 .

75. 13,2.

76. Matthew 23,37-38.

77. 11,20-24.

78. 14, 58-9.

79. Vv. 52-58. 
committed, and if one witness said the third day or hour and the other said the fifth, then the evidence of both was invalid. ${ }^{80}$ It is therefore possible that the witnesses, although agreeing on Jesus' words concerning the destruction of the temple, disagreed about where, or more likely when, he spoke them.

However, Matthew's implication that the evidence of the witnesses about the temple did agree, is arguably stronger than Mark's evidence to the contrary, since there would have been no cause for the high priest to demand why Jesus did not answer the witnesses, if their evidence was invalid. ${ }^{81}$ The evidence indicating that Jesus was condemned for blasphemy arising out of the temple threat, is supported by evidence of the substantive law. For it has been seen that following the broad definition of Leviticus 24,15, in Jesus' day, as exemplified in connection with Jesus' forgiveness of sins, it was considered blasphemy to "dishonour" God. The temple was associated with God's honour because his name rested there. ${ }^{82}$ It was obviously permissible for God himself through the prophets to threaten the destruction of the temple, ${ }^{83}$ but for a man to do so, might well have been considered blasphemous. The penalty expressed at Leviticus 24,15 for "cursing God" (interpreted as including dishonouring God) is that the offender shall "bear his sin". The same verbal root, $q-1-1$, is used of cursing father or mother at Leviticus 20,9 and there the penalty is death, so we may suppose that "bear his sin" should be so understood at $24,15$. . $^{84}$

From this review of the Marcan and Lucan evidence concerning Jesus' trial before the Sanhedrin, aided by evidence of the procedural and substantive Jewish law affecting blasphemy, it seems more probable that Jesus was found guilty of blasphemy in that he had threatened to destroy the temple.

There has been much debate over whether the Sanhedrin possessed the power to execute the death penalty in A.D.33, but the preponderance of evidence is that it did not. The instances where the Jews did cause death in this period appear to have been cases of 'lynch law' rather than of judicial sentence. ${ }^{85}$ Admittedly, there is a Talmudic saying that forty years before the destruction of the temple the right to try capital cases was taken from Israel, ${ }^{86}$ which, allowing some imprecision, could mean that the Sanhedrin's power to carry out the death penalty survived until A.D.33. It seems more likely that forty years was used to signify 'a long time' and that a cessation at the commencement of direct Roman rule of Judaea in A.D.6 is

80. Sanhedrin 5,1 .

81. 14,60 .

82. 1 Kings 8,29 .

83. Micah 3,12; Jeremiah 26,6,18.

84. So, J. D. M. Derrett, Law in the New Testament, Darton, Longman \& Todd (1970), p. 454; contra, Cohn, supra n. 57, p. 101.

85. Thus Stephen at Acts 7, 57-60, and James, the brother of Jesus at Josephus, Antiquities 20, 200-203.

86. Sanhedrin 4la. 
intended ${ }^{87}$ Moreover, John reports the Jews as saying, "It is not lawful for us to put any man to death" 88 and even in $c$. A.D.90 there were probably those who could have corrected John or his source if this tradition had been wrong.

The strongest evidence against the Jews' possession of the power to impose the death penalty arises from the nature of Roman rule. As noted above, following Augustus' deposition of Archelaus in A.D.6, an equestrian praefectus was appointed to govern Judaea as a Roman province. Because the ordo, a list of crimes for which a citizen in Rome could be punished, was established long after Rome acquired provinces to administer, the praefectus based his jurisdiction on his imperium which he held just like a proconsul or imperial legate who governed a province. Imperium, although limited by statute, originated in the unbridled royal power which the consuls inherited from the kings of Rome. In criminal jurisdiction the imperium gave the powers coercere et animadvertere (to compel obedience and to punish). Although, as mentioned, Rome had granted the Jews permission to follow their own laws where public order was unaffected, it is most unlikely that Tiberius had allowed them to exercise the death penalty. The Edicts of Augustus to the proconsul of Cyrene in 7-6 B.C. had shown this power to be reserved to the governor of a province, for in writing about non-capital charges Augustus adds, "this does not apply to capital charges which the governor must hear and decide either by himself or by providing a jury." 89 The admitted exception in Judaea to this rule was that, according to Josephus ${ }^{90}$ and a wellknown temple inscription, ${ }^{91}$ the Sanhedrin was allowed to execute trespassers on the inner temple, but such trespassers could ipso facto only be Gentiles. ${ }^{92}$ The above cumulative evidence persuades us that the Sanhedrin did not have power at this time to execute the death penalty and so is unlikely to have pronounced it vainly. Mark thus correctly states that they judged (katekrinan) Jesus to be worthy of death (enochon thanatou), ${ }^{93}$ i.e., a judicial opinion rather than a sentence. ${ }^{94}$

Consequently, to secure Jesus' death, the Sanhedrin had to arrange for two or three of its members, or others, to lay such information against Jesus as would

87. Josephus, War, 2,117, reports that Augustus on appointing Coponius to be the first praefectus of Judaea in A.D.6, delegated to him the power to rule on his behalf and exercise his authority including the right to inflict capital punishment.

88. 18,31 .

89. Quoted by Sherwin-White, supra n. 43, p. 15.

90. War, 5,194.

91. The Clermont-Gannau inscription, "No foreigner is to enter within the forecourt and the balustrade around the sanctuary. Whoever is caught will have himself to blame for his subsequent death."

92. Although, concerning proselytes, see Booth, Contrasts, supra n.2, p. 104, n.30A.

93. 14,65 .

94. Cf., V. Taylor, St. Mark, Macmillan (1953), p. 570. It is arguable that as there was no power to impose the death penalty, there were no capital cases in Jewish law, and if there were no capital cases, the special rules affecting them, such as the trial being in daylight, did not apply after A.D. 6. However, this smacks of sophistry, and 'capital' was more probably construed as meaning a case where the accused, if found guilty, would be 'deserving of death' under Jewish law. 
induce Pilate to order the Roman death penalty, namely crucifixion. And such was the punishment for sedition and political insurgency. ${ }^{95}$ Hence the meeting of the Sanhedrin the following morning which is attested by Mark, Luke and John. ${ }^{96} \mathrm{We}$ may accept Luke's evidence ${ }^{97}$ that it was at this morning meeting that the high priest addressed to Jesus the questions about the Messiahship discussed above. Jesus' admission of the Messiahship, which involved, in Jewish expectation, inheritance of the royal throne of David, and hence a kingly claim, provided the evidence the Jews wanted in order to found a charge of treason before Pilate.

The question naturally arises: why at the nocturnal meeting did the Sanhedrin investigate and find proved a charge of blasphemy arising from Jesus' words against the Temple when, to secure their presumed object of Jesus' death, it was only necessary to find for Pilate evidence of treason which they achieved in the morning meeting? The answer may lie in the politics of the Sanhedrin. For, although controlled by the Sadducees, the Sanhedrin, as noted above, contained a substantial $P$ harisaic minority, and the Pharisees received much popular support. The arrest of Jesus by the Sadducean chief priests in order to arraign him before the hated Pilate would probably have been condemned by the Pharisees, and hence the people, if Jesus had not then been accused before the Sanhedrin of a breach of Jewish law. Once Jesus had been convicted of a death-deserving offence against Jewish law, however, the Pharisees probably did not object to the sentence being ordered by a Roman praefectus for a Roman offence, given the unfortunate circumstance of Roman dominion.

\section{Proceedings before Pilate}

Sherwin-White has noted how well the procedure before Pilate accorded with the Roman Court practice, extra ordinem. ${ }^{98}$ Because legal proceedings in a province did not normally concern a crime in the Roman ordo (list of crimes), which primarily contained the crimes of high society - and even if the crime, like treason, was in the ordo, ${ }^{99}$ the praefectus was not required to follow that procedure - the praefectus had complete freedom in the charges he accepted and in the penalties he imposed, apart from the mandatory cases of crucifixion (the arbitrium judicantis). The praefectus tested the facts alleged in the charge by his own cognitio (investigation) rather than by the method of examination and cross-examination by advocates as adopted by the common law.

98. Supra, n. 43.

99. The Lex fulia maiestatis enacted by Julius Caesar in 46 B.C. created the capital offence of crimen laesae maiestatis, the crime of injuring the majesty of the Emperor, and under this head of the ordo insurrection and treason were prosecuted at Rome.

95. Paulus, the 3rd-century jurist writes: "auctores seditionis et tumultus vel concitatores populi pro qualitate dignitatis aut in crucem tolluntur aut bestiis obiiciuntur aut in insulam deportantur" (Sententiae 5.22.1); $c f$., the Neronian persecution of Christians (Tacitus, Annals 15, 44).

$96.15,1 ; 22,6 ; 18,28$.

97. 22,66 . 
Thus, in a cognitio extra ordinem the accusation is not of a particular crime, but of facts upon which the praefectus is invited to adjudicate. This freedom to decide whether the facts alleged constituted a crime is shown by Pilate's response in Luke to the chief priests' allegation - "I find no crime in this man." It also seems to be implicit in Festus' reply about Paul to the chief priests, ". . . if there is anything wrong about the man, let them accuse him."' Thus, the evidence of the proceedings before Pilate in Luke's report seems to be the more probable. There the Jews alleged specific facts, namely that they found Jesus to be perverting the nation (i.e., inciting the people against Rome), forbidding the giving of tribute to Caesar, and claiming to be Christ, a king. ${ }^{3}$ Mark asserts that the chief priests "accused Jesus of many things", which is strangely placed after Pilate's immediate question on arrival, "Are you the king of the Jews?"4 In John, Pilate more credibly opens the proceedings by asking the Jews what accusation they bring, but there is less credibility in the Jews' reply, "If this man were not an evildoer, we would not have handed him over", 5 since the chief priests would have known that such an allegation was insufficiently specific to lead to a conviction. Pilate's next question to Jesus, whether he was the king of the Jews, ${ }^{6}$ suggests that John's tradition (like Mark's) has omitted an accusation by the Jews to this effect. The other accusation by the Jews in John, "We have a law and by that law he ought to die because he has made himself the Son of God", ? also lacks credibility, being opposed by the evidence of legal history, as discussed above. Pilate's alarm at this allegation would admittedly be understandable since as a Roman and inheritor of Greek culture, he would have understood Sonship of God as a claim to supernatural or divine status. $^{8}$

However, it is unlikely that the chief priests would ask Pilate to condemn Jesus for a religious offence against Jewish law. They would know that Pilate would refuse to involve himself in such matters; thus, in John's report Pilate had previously said, "Take him yourselves and judge him by your own law." Similarly, Festus, the procurator (later title for praefectus) of Judaea c.A.D. 60-62, reports regarding the Jews' accusations against Paul: "When the accusers stood up, they brought no charge in his case of such evils as I supposed; but they had certain points of dispute with him about their own superstition and about one Jesus, who was dead, but whom Paul asserted to be alive. Being at a loss how to
$1.23,4$
2. Acts 25,5 .
3. 23,2 .
4. 15,2-3.
5. $18,29-30$.
6. 18,33 .
7. 19,7 .
8. Romans and others affected by Hellenism would understand the title, 'Son of God', to signify a 'divine man' who, because he effected miracles of healing or other wonders, was reputed to be descended from the gods. In this way, Alexander the Great, Pythagoras, Plato and several fraudulent persons were assigned divine ancestry. See further Booth, Contrasts, supra n. 2, pp. 175-7.

9. 18,31 . 
investigate these questions, I asked whether he wished to go to Jerusalem and be tried there regarding them."10

The more probable Gospel evidence, since it is supported by the evidence of legal history, is that Pilate first asked the Jews what accusation they brought against Jesus, and that the Jews in reply accused him of perverting the nation, forbidding the giving of tribute, ${ }^{11}$ and of claiming to be Christ, a king. These charges may be the 'many things' to which Mark refers. ${ }^{12}$ The evidence of Pilate's question, "Are you the king of the Jews?", attested by all three independent witnesses, ${ }^{13}$ is persuasive that this was the main charge brought against Jesus; this would certainly seem the most serious to Pilate in the unsettled circumstances of the time. For Josephus records how after the death of Herod the Great (B.C.4) Judaea was filled with insurrection; Judas, Simon and Athronges led rebellions and acclaimed themselves kings, and Josephus summarises: "Anyone might make himself king as the head of a band of rebels whom he fell in with . .."14 It cannot have helped Jesus' cause that Barabbas, whose freedom the crowd chose by Passover custom rather than Jesus', had been awaiting crucifixion for murderous insurrection. ${ }^{15}$

Nonetheless, despite the natural Roman sensitivity to royal claims, Pilate, according to Luke, ${ }^{16}$ after questioning Jesus about his kingship, decided in exercise of his arbitrium judicantis not to recognise the allegations as constituting an offence. Luke's assertions here are supported by the evidence in Mark's and John's accounts of Pilate's reluctance to convict Jesus. ${ }^{17}$ Bearing in mind the febrile political atmosphere, the likelihood that the Jews could prove that Jesus had claimed to be Messiah, and that Jesus did not defend the allegation, this reluctance to convict is initially surprising. ${ }^{18}$ Pilate probably did accept the Jewish allegations of Jesus' Messianic claims, but perhaps could not take those claims seriously. The clue may lie in the mockery. The taunting of Jesus and his adornment in royal trappings by the soldiers of both Pilate and Herod ${ }^{19}$ (infra) suggests that neither Pilate nor Herod could conceive that the humble Galilean peasant who refused to defend himself against a capital charge, could be a threat to Rome or to law and order, whatever titles he might care to give himself.

10. Acts $25,18-20$.

11. Indeed, Luke relates at 20,20 that the spies who asked Jesus about tribute to Caesar, intended to preserve his reply so as to deliver him up to the jurisdiction of the Governor.

12. 15,3 .

13. Mark 15,2; Luke 23,3: John 18,33 .

14. Antiquities 17, 273-85.

15. 15,7 .

16. 23,4 .

17. Mark 15,9,14; John $18,31,39 ; 19,6$.

18. Pilate might have been less reluctant to convict Jesus if he had known of the people's earlier intention reported by John: "Perceiving then that they were about to come and take him by force to make him king, Jesus withdrew again to the hills by himself' $(6,15)$.

19. Mark 15,17-19; Luke 23,11. 
So, on learning that Jesus came from Galilee, Pilate sent him to Herod (Antipas) who happened to be in Jerusalem at the time. ${ }^{20}$

\section{Proceedings before Herod Antipas}

The ignorance of the other Evangelists concerning these proceedings should not constitute counter-evidence to Luke's assertions since even Mark was writing over 30 years after the trial. ${ }^{21}$ However, if there was no possible reason why Pilate should consider that Herod could claim jurisdiction over Jesus' case or that he should be offered jurisdiction out of courtesy, the absence would arguably be counter-evidence. Accordingly, the conflict of laws will be considered.

It is commonplace to-day for a Court to exercise criminal jurisdiction over any person present in its territory if the crime is alleged to have been committed in its territory; indeed, the ground for jurisdiction is the commission of the crime in the territory, and the accused who has left the territory may be extraditable from his country of refuge. It seems likely that forum delicti was also the basis of criminal jurisdiction in the early years of the Roman Empire, but that with the growth of legal theory the concept of a person being triable in the province of his residence (forum domicilii) arose. ${ }^{22}$ It is unlikely, however, that the Courts of an accused's country of residence ever had jurisdiction to the exclusion of the Courts of the place of commission of the act, since it is usually the law and order of that place which is jeopardised. In the times of Trajan (A.D.98-117) or Hadrian (A.D.117-138) the jurist Celsus wrote that it was clear that the governor of the province in which the act was done ought to handle it; he added that some governors sent the accused back to his province of origin after a preliminary investigation, but that this should only be for special reason. ${ }^{23}$ However, the position may well have been more fluid eighty years or so earlier in Jesus' day, so we should not allow the uncertain evidence of the law to outweigh Luke's evidence. Moreover, Josephus notes the formidable influence of Herod the Great, Antipas' father, beyond his realm, saying, "no other sovereign had been empowered by Caesar, as he had, to reclaim a fugitive subject even from a state outside his jurisdiction."24 It may be that Pilate, knowing of Antipas' father's unusual privilege of extradition, offered Antipas jurisdiction over Jesus, a man from his tetrarchy, ${ }^{25}$ as a courtesy; this would accord with Luke's report that their previous enmity was dissolved that day. ${ }^{26}$

The weight of Luke's evidence concerning Pilate's transfer of Jesus to Antipas is increased by his apparent accuracy over detail in the report. His assertion of hostility between Pilate and Herod is supported by evidence of an incident

20. Luke 23,6-7.

21. See n. 4 (1).

22. See generally on this conflict point, Sherwin-White, supra n. 43 (1), pp. 29-31.

23. D.48.3. 11.

24. War 1,474 .

25. A tetrarchy, literally government of a quarter of a territory, had come in Roman times to mean merely the area governed by a minor native dependent ruler.

26. 23,12 . 
probably occurring c.A.D.31 which is recorded by the Alexandrian Jewish writer, Philo (c.B.C.20-A.D.50). According to Philo, four sons of Herod the Great (of whom Antipas would clearly be one) protested to Pilate on behalf of the enraged populace when Pilate introduced into Herod's palace in the holy city religiously offensive votive shields. Moreover, they sent letters of complaint to Emperor Tiberius who severely rebuked Pilate and ordered the removal of the shields to Pilate's palace at Caesarea. ${ }^{27} \mathrm{~A}$ sourness in Pilate's previous relations with Herod is consequently credible!

That Herod accepted the offer of jurisdiction is supported by Luke's report that he questioned Jesus at length, and that the chief priests and scribes were allowed to make their accusations. ${ }^{28}$ Admittedly, his transfer of Jesus back to Pilate would be consistent with a refusal to adjudicate, but there seems to be no reason to doubt Luke's assertion that the sending of Jesus back indicated that Herod found him innocent. ${ }^{29}$ Further, a rejection of Pilate's offer of jurisdiction would hardly have produced the reported repair of their relations.

Again, Luke's report that Herod desired to see Jesus and to witness him work a miracle, ${ }^{30}$ seems credible since Mark reports that when Herod heard of Jesus' ministry, he believed that John the Baptist whom he had beheaded, had been resurrected! ${ }^{31}$ But Jesus was as reticent before Herod as before Pilate so that Herod mocked him, clothed him like a king, and returned him to Pilate. ${ }^{32}$

Luke does not state the nature of the accusations made by the chief priests and scribes before Herod. Like Pilate, Herod would not normally ${ }^{33}$ have been concerned with breaches of Jewish religious law, though partially Jewish himself, ${ }^{34}$ since the local Sanhedrins would adjudicate upon such matters in his tetrarchy. ${ }^{35}$ Equally, while he assiduously curried favour with Emperor Tiberius, ${ }^{36}$ it is doubtful whether he would have been particularly disturbed by the allegations that Jesus forbade the giving of tribute to Caesar. He would have been

27. Legatio, 299-305. A grievance of Herod may have been Pilate's slaughter of Galileans who were in Jerusalem to sacrifice (Luke 13,1).

28. 23, 9-10.

29. Although the party who supported the return of the Herodian dynasty to power in Judaea (the Herodians) had, according to Mark, plotted with the Pharisees to kill Jesus early in his ministry $(3,6)$, and attempted with them to incriminate Jesus over paying tribute to Caesar $(12,13-17)$. Cf., the doubtful story of Antipas' father's intent to kill the baby Jesus (Matthew 2,7,16).

30. 23,$8 ; c f .9,9$.

31. 6.16 .

32. Luke 23,11 .

33. Although, as in the case of the errant shields noted above, he was willing to complain of such a breach if it would bring him political advantage in favour with the people or embarrassment of an enemy.

34. His mother, Malthake, was a Samaritan but his father, Herod the Great, was a descendant of the Idumaeans who were forcibly converted to Judaism by John Hyrcanus c.130 B.C.

35. Schürer, supra n. 23(1), Vol. II, p. 184 et seq.; Sherwin-White, supra n. 43(1), p. 142.

36. Most notably in the negotiations between Vitellius, governor of Syria, and the King of the Parthians; Herod sumptuously entertained both in a tent on the new bridge over the Euphrates, and then sent a complete report of the negotiation to Emperor Tiberius, completely up-staging Vitellius whose function it was to report (Josephus, Antiquities 18, 104-5)! 
more alarmed by the allegations that Jesus was perverting the people, and claiming to be a king. As already mentioned, according to Mark, ${ }^{37}$ Herod believed Jesus to be John the Baptist returned to life, and this was probably because Jesus' preaching and attraction of the crowds was reminiscent of John. It was because Herod had feared that John's preaching and influence over the people would lead to a rebellion, that he had imprisoned John, ${ }^{38}$ although a contributory factor was probably John's fierce condemnation of Herod's marriage, in contravention of Jewish law, to his half-brother's wife. ${ }^{39}$ Accordingly, it seems likely that the accusations of the Jews before Herod would be that Jesus had been inciting the Jews of Galilee to rebellion, and claiming there that he was a king.

Luke reports that Jesus had previously been warned to leave Galilee because Herod wanted to kill him, ${ }^{40}$ so that Herod's return of him to Pilate must have been due to a wish for strategic reasons not to disagree with Pilate, or because on actually meeting Jesus, he could not, as suggested above, treat him as a credible threat to law and order.

Perhaps if Pilate had not been involved, and Herod himself had arrested Jesus in Galilee, Herod would have imprisoned or killed Jesus without trial. His arbitrary treatment of John shows that executive action rather than judicial enquiry was his approach to situations affecting law and order. Josephus writes of John's end: "Herod decided therefore that it would be much better to strike first and to be rid of him before his work led to an uprising, than to wait for an upheaval, get involved in a difficult situation, and see his mistake." 41

\section{Pilate's judgment}

All the Evangelists attest Pilate's wish to release Jesus. In Mark and John, Pilate suggests to the Jews that he should release Jesus pursuant to the annual amnesty for one prisoner at the Passover, but the Jews demand instead the release of Barabbas, the rebel. ${ }^{42}$ In Luke, the Jews cry out for Barabbas' release although the Passover amnesty is not mentioned. ${ }^{43}$ There does not appear to be any Jewish or other source which supports the evidence of a Passover amnesty, but the evidence of Mark and John that it prevailed in Jesus' time is not opposed by contrary evidence.

John's assertion is compelling - that it was the Jews' warning that if he released Jesus he was not Caesar's friend, which caused Pilate to change his mind and order

37. 6,16 .

38. Josephus, Antiquities 18, 118-119.

39. Mark 6,17-18.

$40.13,31$, and see n. 29(2).

41. Ibid.. If, indeed, John was beheaded because of Herod's rash vow to Salome, then arbitrariness was compounded with caprice (Mark 6,21-28).

42 . 15,$9 ; 18,39$.

43. 23,18. Some manuscripts of Luke's Gospel do contain the explanation, "Now he was obliged to release one man to them at the festival", but it is usually considered a scribal gloss conforming the text with Mark 15,6 and Matthew 27,15. 
Jesus' crucifixion. ${ }^{44} \mathrm{His}$ failure to heed this warning might well have reverberated in Rome, and its likely authenticity is heightened by it being so politically apposite in this period. According to Josephus, Julius Caesar in his aforementioned decree appointing Hyrcanus and his sons to be ethnarchs and high priests, declared that they should be "numbered among our particular friends", and Philo refers to Agrippa, (grand-son of Herod the Great) as a friend of Caesar also in a political rather than a personal sense..$^{45}$

The historicity of the Gospel evidence about Pilate's judgment is supported by the evidence of Roman law. Thus, because the cognitio extra ordinem originated in the governor's executive action by virtue of his imperium, the governor rather than pronouncing a verdict of guilty or not guilty, simply ordered the penalty. Pilate, following this procedure, ordered Jesus to be scourged and delivered him to be crucified. ${ }^{46}$ Again, it conformed with Jewish law that Pilate, in Luke, declared that because nothing deserving death had been done by Jesus, he would merely chastise him and then release him. ${ }^{47}$ For although it sounds bizarre to a modern western lawyer that an accused, found to have done nothing criminal, should be chastised, this was a permissible option in the exercise of coercitio (the ruler's enforcement of order) as contrasted with cognitio (judicial investigation of facts, possibly followed by penalty).

There were three levels of beating - fustes (cudgels), flagella (whips) and verbera (lashes). The beating with fustes being the least painful of the three, was the executive action linked with a warning, so Luke's report of Pilate's proposal here accorded with Roman practice. Not surprisingly, a severe beating accompanied the capital sentence, so that Mark is precise and correct in asserting, "having scourged Jesus [Pilate] delivered him to be crucified." 48

\section{Conclusion}

This attempt to weigh the evidence of the Gospels, of other roughly contemporaneous writers, and of Jewish and Roman law, suggests that on a balance of probability the course of the trials was as follows.

1. Jesus was arrested by order of the chief priests of the Jews.

2. He was found guilty by the Sanhedrin of blasphemy on the evidence that he had threatened to destroy the temple, and he was adjudged worthy of death.

3. The chief priests or other agents of the Sanhedrin alleged before Pilate that Jesus had perverted the nation, forbidden the giving of tribute, and claimed to be the King of the Jews.

44. 19,12-13.

45. In Flaccum, 40.

46. Mark 15,15; Luke 23,25; John 19,16.

47. 23,15-16.

48. 15,15 . 
4. Initially, Pilate in exercise of his discretion under the cognitio procedure refused to accept that these allegations showed that Jesus' claims constituted a threat to Roman dominium and therefore a crime, and he sent Jesus to Herod, tetrarch of Galilee, who agreed with him.

5. Finally, Pilate, persuaded by fear of the political consequences to himself if he did not punish an alleged native King, ordered that Jesus be scourged and crucified.

During this survey we have observed how (a) to achieve Jesus' death without outraging the Pharisees and people, the chief priests had to secure his conviction for a Jewish offence deserving death, and then persuade a Roman Court that he was guilty of a Roman capital offence; that (b) the offence of threatening the temple was not punishable by Rome, while the offence of sedition alleged by the Jews before Pilate, was not criminal in their own Courts; that (c) a Roman governor was willing to cede jurisdiction to a neighbouring native puppet ruler; that (d) Pilate's preference to take executive action by warning Jesus and ordering chastisement, was over-ridden by the Jews' demands for the penalty of crucifixion; and that (e) Greek secular culture, represented by a Roman provincial governor, was confronted by theocratic Jewish culture which, nevertheless, by its crowd averred, "We have no king but Caesar."

The conflict of laws, jurisdictions and cultures thus revealed were tragically symbolised in the crucial superscription (attested by all Evangelists ${ }^{49}$ and conforming with Roman practice), "Jesus of Nazareth, the King of the Jews" which, adds John,,$^{50}$ was written in Hebrew, in Latin and in Greek. 